\title{
VIOLENCE IN THE BRAZILIAN SCENARIO: RISK FACTORS OF ADOLESCENTS FACING A CONTEMPORARY REALITY
}

\author{
Luciana Souza Borges ${ }^{1}$, Heloisa Moulin de Alencar ${ }^{2}$
}

\begin{abstract}
Introduction: We noticed an emphasis on mortality from external causes, especially homicides that occur among the male youth population, characterized as aggressor and victim, currently representing one of the major problems for public health. Brazil has, then, been concerned with interventions aimed at decreasing youth victims of violence and the promotion of a culture of peace. Objective: For this purpose, we consider essential to understand the psychosocial risks that may be present in the developmental trajectory of this population. This is the major purpose of this study. Methods: To understand violence in the contemporary Brazilian scenario, we present some results obtained through a literature review. Results: Thus, recent studies show that the risk factors that may affect young people throughout their life cycle are of various levels: physical, psychological, economic, sociocultural etc. Moreover, the protective factors that young people acquire in adverse contexts will also have to be addressed for a more comprehensive understanding of the topic. Thus, we find as relevant risk factors: low socioeconomic status and perceived impossibility of consumption of material goods; poor housing conditions; experience and exposure to intrafamily and community violence including police violence; exposure and contact with drugs; history of physical and psychological abuse; low education; existence of family members with low education, unqualified to work and involved in crime; access to weapons; belonging to gangs; experience of long periods of social exclusion and poverty; feeling threatened by violence and powerlessness in the face of it; and belief that violence is a legitimate solution to social conflicts. Regarding protective factors, studies have highlighted social support networks (school, work, friends, and institutions), skills to protect and negotiate rights and interests, positive images of others, the expectation of help from neighbors and the community in general, high self-esteem and family supervision. Personal factors that contribute in this direction, such as self-esteem and spirituality were also highlighted. Conclusion: However, the interpretation given by the subject suffering a certain stress will determine the degree of impairment in their development. This is one of the reasons why the risk factors must be associated with the protective factors, because not all subjects who undergo the same psychological and social stressors will become vulnerable to other harmful aspects to their development such as involvement in crime by instance. For this reason, describing groups and risk factors becomes essential to seek specific interventions, for gender, age, color, geographical space and social and economic conditions are important variables to specify forms of incidence and prevalence of violence. However, it will be on the individual considered as a whole (physical and psychological), that violence will ensue, either as victim or as perpetrator.
\end{abstract}

Key words: violence; adolescents; psychosocial risk.

\section{INTRODUCTION}

We briefly highlight the perspective that is admitted in the writings about violence, because, we analyze the phenomenon from its multidimensional characteristic, which can be translated as crimes, wars and familiar violence, among other possibilities. Furthermore, we also stand out the strong complexity that violence has been considered in several studies, seen as

1 Coordenadora, Professora e Pesquisadora do Programa de Pós-Graduação em Segurança Pública, Universidade Vila Velha (UVV) - Vila Velha (ES), Brasil.

2 Professora do Curso de Graduação em Psicologia - UVV - Vila Velha (ES), Brasil, Professora do Departamento de Psicologia Social e do Desenvolvimento e do Programa de Pós-Graduação emPsicologia da Universidade Federal do Espírito Santo (PPGP/UFES) - Vitória (ES), Brasil.

Corresponding author: Luciana Souza Borges. E-mail: luciana.borges@uvv.br

Suggested citation: Borges LS, Alencar HM. Violence in the brazilian scenario: risk factors of adolescents facing a contemporary reality. Journal of Human Growth and Development. 25(2): 194-203. http://dx.doi.org/10.7322/jhgd.103015

Manuscript submitted: sept 29 2014. Accepted for publication Dec 192014. 
result of varied determinations and associated to unfair and unequal social structures for their citizens.

Therefore, the literature review for this work indicated different ways and important changes in the analysis of the violence that has been raging on Brazil, as well as in the interpretation of human rights that follow this issue. The comprehension of violence and the planning of a collective action itself in favor to this problem is discussed from an interdisciplinary study proposal involving social sciences, collective health (epidemiology) and psychology, although, other areas that could collaborate, such as criminology and the criminal right, for instance, are admitted ${ }^{1}$.

This way, we accept from some analysis, the need to consider certain aspects in the study of this theme: violence is a social and historical phenomenon, so it has to be differed in time and space; violence of individuals and of small groups must be related to the State violence and the stablished order; social inequality and the economic and social privation are fundamental aspects in the specific studies of criminality; the prevention of the problem is desired, describing groups and risk factors and searching for specific interventions; gender, age, color, geographic space and social and economic conditions are important variables in order to specify the ways of incidence and the prevalence of violence; it is in the individual, considered as a whole (physical and psychic), that the violence is effective, either as a victim or aggressor ${ }^{1}$.

Sharing a similar concept of violence, some authors conclude that it is no longer possible to understand the phenomenon as something that ends at the individual level. On the other hand, it is established that the identities themselves must be acknowledged as fluid and constituted by social differences and by the established power relations, and thereby causing several ways of violence or possibilities to be violent ${ }^{2}$.

Such is the magnitude of violence phenomenon, that OMS proposes an ecologic model for its comprehension, with the intention to explain multiple causes, from biological and personal factors up to relational, community and social ones. And, from a human development perspective, we can consider different elements in each age group as influence for the individual to become victim of violence or even the aggressor ${ }^{1}$. Regarding youth, specifically, we highlight that subjects involved with offenses come from families with many conflicts, whose solution tends to occur through violent approaches. Moreover, these young people live in a much more frequent way with criminalized adults, belonging to the same family or from friendship relations ${ }^{3}$.

However, to understand the violence that is part of the contemporaneous scenario captured in its complex nature, it is necessary to focus on the social, human and collective health science studies. Therefore, we can see some specific results on violence in Brazil, obtained through a bibliographic research.

\section{Violence in the Brazilian scenario}

It is highlighted that the democratization processes lived by societies with similar profiles to the Brazilian one, in which social injustice and violation of human rights have always been frequent, are not satisfactory to modify the picture of violence historically rooted in these contexts. By reporting the reduction of the State presence in social areas in the last two decades of the twentieth century, we delineate the social crises arising from this situation, which culminated with the growth of the social exclusion and poverty. Ergo, despite the expectations raised by the democratization regarding the protection of human rights and citizenship for all the society, it is possible to find illegality and arbitrariness that have been lining off the relations between the Brazilian govern and the populations facing risky situations ${ }^{4}$.

Accordingly, there are serious violations of the human rights, mainly with the population presenting the worst life conditions. Thus, having the city of São Paulo as focus, it was found a result of 2.248 victims of this type of violation for the year of 2000, considering $80,9 \%$ related to summary executions, $18,2 \%$ to police violence and $0,8 \%$ to lynching. The young population was the most affected in the three segments ${ }^{5}$.

It is also interesting to observe the relevance of the man in topics related to the generalized violence, in several types of studies - guttersnipes (boys and girls), magnitude and dynamic of offenders, mortality and morbidity of patients, death caused by homicides, vulnerabilities for drug use, suicide cases, life expectation, etc. This way, it is possible to realize men having more social disadvantage in all the aspects evaluated. We note, then, the relation between the ways of living the masculinity and the culture of violence, indicating the gender issue, historically built ${ }^{1}$.

It is in the long-term values, which structure the patriarchal occidental culture that the sexist elements will emerge, especially in the discourse and behavior of social delinquents. This way, the patriarchal view, when ritualizing the masculine role as subject of sexuality and the feminine one as their object, puts the men in the action and decision place, naturalizing their social position of power and violence agent when articulating both plans, the sexuality and sociability one. In the criminality context, the violent subjects will focus on this belief of the male role as a possibility of power and imposition of their own will, what has been characterizing the excesses of this kind of violence in the masculine population, in relation to the victims and the aggressors as well ${ }^{1}$.

Considering the gender and $a_{g e}{ }^{6}$, variables all-together, we point important differences when the kind of violence analyzed is physical aggression, in the occurrences held in the city of Rio de Janeiro. Thus, women are more affected in a fertile period of their lives, from 20 to 40 years old and men are more attacked when a little bit younger, from 15 to 30 years old. However, these figures are modified when the physical aggressions are observed in slums, because, besides the proportions be much 
higher than in the cities, they affect both men and younger women.

Regarding firearms ${ }^{7}$, specifically, we bring analyses about the Disarmament Statute (Law $10.826 / 03)^{1}$, standing out the need to broaden this discussion to beyond the perception of guns as simple causes of violent situations. This way, the paper highlights the fact that the use of firearms represents a "violent sociability" (p. 142), that precedes is part of the current social relations present in the urbanization process of big centers.

Anyway, we highlight the studies disclosed by Parliamentary Office of Science and Technology ${ }^{8}$, showing the existence of a positive relation between possession of firearms and the occurrences of actions due to their use, such as, homicides and suicides. Although, in Brazil, specifically, the most serious problem is related to the homicide crimes carried out with illegal guns. In this sense, differences regarding gender and age must also be established, having the young people more victimized, mainly men.

In such important interdisciplinarity applied in the field of violence and health ${ }^{1}$, as a proposal for a better comprehension of the problem, the epidemiology studies about the impact of violence on health are considered very relevant. It is mentioned the changes in the field of health that started in the sixties, when a transition in the mortality scenario occurs in Brazil \% of the infectious parasitic diseases for violence \%, that followed the urbanization process in the period. In the nineties more than one million people died in Brazil, victims of violence and accidents, having 400 thousand deaths resultant from homicides, fact that had a relevant impact for personal and collective health.

In these studies ${ }^{1}$, related to the themes of violence and health, the Brazilian reality is similar to the international trend. Thus, the mortality due to external causes is highlighted, mainly homicides occurred among the male young population, characterized as aggressor and victim, besides the importance of the correlations of this type of violence with the life conditions stablished. There is a huge growth of the publications on the theme from the first half in the decade of 2000, when some researchers start to study some specific cities in Brazil and stand out that the nowadays the homicide rate represents one of the biggest issues for public health.

Based on these indications and on the proposals from the international bodies, like the World Health Organization (WHO) and United Nations (UN), Brazil is concerned with legislations (National Policy to reduce mortality caused by accidents and violence) that are directed to the prevention of violence and the promotion of health aiming at reducing the number of victims and consequently the promotion of a peace culture ${ }^{1}$.

The work also highlights the research ${ }^{9}$ that analyzed the scientific production about violence and health from 2003 to 2007, through national journals, which the following themes are seen in the period of the production: theoreticalmethodological constructions $(14,06 \%)$, violence and gender $(23,27 \%)$, violence and childhood/ adolescence $(30,94 \%)$, violence against the elderly $(1,02 \%)$ and violence in specific situations $(30,68 \%)$, for instance, in the work context, leisure centers, media etc.

On this result, it is possible to verify aspects of violence, still not very studied, despite its social importance, like the violence against the elderly and homosexuals that occur in socio-educative areas, the violence linked to the drug dealing, violence with disable people and with Indians. Besides, there are three important aspects that need to be improved in future researches: an insufficient characterization of the coping strategies in situations of violence; a lack of results systematization that could favor the elaboration of future interventions; few studies that prioritize the comprehension of the violence phenomenon from the aggressor point of view, because it is necessary to enable actions for both direction \% the victim and the aggressor.

Still about the analyses of scientific productions, this time in relation to health promotion of the Brazilian young population ${ }^{10}$, the majority of the work identified was about epidemiologic researches focusing on the biomedical. The actions described in these publications focus on group interventions for the prevention of risk behavior in sexual and reproductive health, even before the diversity of factors related to the adolescents integral health.

Anyway, from these considerations, we can find the emphasis that rests on the youngest population, when the violence in the Brazilian scenario is approached and we observe the need to elaborate specific interventions that interfere and prevent this population to get involved in risky circumstances. However, for this last purpose with preventive characteristics in the ambit of violence, which young people can be submitted to, we find essential to know the Brazilian young people and the psychosocial risks as well that may be present in its development trajectory. This is the main goal of the article we present next.

\section{Brazilian Adolescents: who are they?}

Before analyzing the literature that deals with the Brazilian young population vulnerability, we need to define this stage of human development and present some of its current characteristics in the Brazilian context.

Initially, we inform that the youth term - from the social sciences - and adolescence - from the human sciences - are usually used indistinctly in modern literature with the purpose to deal with this category experiences, concomitantly considered as social and psychological, besides seen as a recent construction in our occidental culture ${ }^{11}$. Adolescence, as now characterized, is a product of the twentieth century as we will discuss later.

From different documents or during distinct moments in history, we can also find some

1 Law 10.826/03 that deals with Statute of Disarmament establishes the prohibition of firearms dealing as a solution for the violence issue (Prando, 2007). 
differences related to age considered equivalent to youth. ${ }^{12}$ This way, for WHO and the Ministry of Heath, this period, which initially was considered as the second decade of life, from 10 to 20 years old, more recently it is covered from 15 to 24 years old ${ }^{2}$. Therefore, even not being able to have a stage of life delimitated, there are some attempts to categorize the adolescence moment (between 10 and 19 years old) and the youth period (between 15 and 24 years old). Due to the changes that have been happening throughout history in relation to adolescence comprehension, it is essential to verify the variables present in different cultures and different historical moments.

Authors from the human development area ${ }^{11}$ use to characterize the adolescence period from 12 and 20 years old, approximately, taking into consideration puberty as the beginning and the end during the moments when the young person starts to accept the adults' roles, as we will see later. There is still a possibility to subdivide this stage in two distinct moments: the first one, starting at age 11 or 12 (named adolescence or initial adolescence), it is considered as a transition period and highlights some important changes related to the child's activity aspects (physical, social and intellectual); the second one started around 16 or 17 years old (titled youth or final adolescence), it is characterized as a consolidation moment of these changes and highlights the identity, the standards of social relationship, the objectives to be reached and roles to be carried out by the young people.

We also draw attention for the conceptual difference during puberty, which is a biological fact - characterized by a group of physical changes that occur during the second decade of life transforming a child body into an adult one - and adolescence, which is a psych sociologic fact - evidenced due to its long duration, but whose characteristics may not coincide in diversified culture or in different history times. Therefore, puberty can be understood as a universal phenomenon, because it depends on a mature calendar that is common to the human species. That is not the same for adolescence ${ }^{11}$.

Thus, adolescence, the way we were familiar with in the beginning of the XXI century $\mathrm{XXI}^{11}$, can be understood as a product of history and the social situations that entangled the century XX. Regarding the occident, it is highlighted the importance of the industrial revolution to break the situation that was going on until the end of the XIX century, which the minority of the children used to go to school and most of them was incorporated in the work world when still living their first decade of life. With the advent of industrialization, a demand for a better formation arose and the lessons were considered something very important. Even when only the middle and upper class children remained in the schools, because the ones coming from the work class were still inserted at work, throughout the XX century this situation changed little by little when schooling started to be mandatory in several countries in the occident ${ }^{12}$.
This schooling phenomenon would have contributed for the formation of a new group, the adolescents, with their own peculiar habits and problems, as there was a distance between the childhood period and the adult stage, caused by a longer permanence at school. This way, boys and girls that were not seen like this in previous moments of the history, but nowadays are considered adolescents in the occident, can be characterized due to still remain in the school system or in any other context of professional learning or looking for a stable job; due to still depend on their parents or live with them; due to carrying out the transition of a system of affection/ attachment, most of the times centered on the family, passing by another one centered on a group of equals, or a system of affection centered on a person of the opposite sex; due to feeling as members of an age culture (the adolescent culture) that is characterized by having their own trends and habits, their own life style, their own values; due to having worries and concerns that no longer belong to the childhood period and do not coincide with the adults one though ${ }^{11}$.

Therefore, the adolescence period is considered the moment of vital cycle, which the construction of identity, the consolidation of personality, the enlargement and diversification of social relations networks, the definition or adoption of social and moral values, the self-image change, etc., is held. There are also the changes found among the teenagers living in different culture or in the so called subcultures, or even inside the same culture, but in distinct historical moments, for instance, the adult status incorporation (build a family, have adult responsibilities, behave as an adult etc.) at an early age, or the opposite, each time later ${ }^{11}$.

In this sense, there are authors ${ }^{13}$ that write about young people of both genders, between 14 and 21 years old and different social classes, living in the city of São Paulo. Despite some aspects that were evaluated as ordinary to these adolescents (like referring to the word responsibility in order to define the entrance in the adult life), the results indicated a diversity of teenagers in the context, mainly regarding the social class and gender, but also related to the oriental ethnicity and aging.

We particularly highlight the restriction in the sense of not finding the characteristics of young people belonging to popular layers in the psychology handbooks and, thereat, the alert for the importance to understand the adolescence process in specific contexts of this order, which the ways of thinking, feeling and acting can be very different. That is the reason for the necessity of socially and historically contextualize the processes of adolescence, owing that any conception on this development stage, will make sense when associated to objective conditions of the analyzed subjects' lives. Ergo, adolescence is seen as a product of life history of each young person that is determined by a social and cultural group they belong to ${ }^{13}$.

2 Such change in age established for the young population occurred due to the extension of this phase, which the responsibilities are not accepted and conceived as adults. 
Regarding the differences found among brazilian adolescents ${ }^{14}$, we stand out the influences coming from historic events and economic fluctuations, besides the gender, race and class inequality. In this sense, when studying the Brazilian young people through census data, since 2006 this population is considered as the one at ages between 15 and 29 years old. In that extent, it is important to discuss the different status found when considering the ages closer to childhood with the following characteristics: "a Student, who does not have a job, most of the time, depends on one of the parents or both, has never had marital experience and children" (p. 34). Thereafter, there are several changes that occur during the adolescence period until the passage to the adult life, when a "great number of people escape of the typical combination of being student-childdependent" (p. 34). In other words, new roles related to family constitution, job acquisition and autonomy are established and will be performed by the individuals leaving the adolescence stage.

In fact, there is a spotlight for a bigger complexity of the life course when we compare the Young population data from 1970 with the 2000 one, indicating that the adult traditional status \% like the one who finished school, started to work, has an independent house and built a family \% is each time more dissolved among possibilities. Within the priority aspects, we bring out the fact of the occurrence at that time, of a raise regarding school attendance and reduction of work in individual groups under 15 years of age ${ }^{14}$.

However, some inequalities related to income and housing conditions still remain, and in a smaller proportion, the inequalities of race and gender: the probability of just going to school and not having a job is higher for young people belonging to families with higher income, living in urban regions; at early ages, there is an advantage in this sense for white female people. Therefore, the change from adolescence status into adult life can occur in different ages, depending on the income, skin color, gender and the domicile situation of the Brazilian subjects. In general, these adolescents take on the adult responsibilities some years before, when comparing to the young people living in developed countries ${ }^{14}$.

In relation to the data available by the IBGE $^{15}$, regarding the social indicators of the Brazilian population, the number of children and adolescents at the age of 14 years old was reduced in the last ten years, because it represented $30,8 \%$ of the total population in 1997 and dropped to 25,4\% in 2007. It was verified that the number of children, adolescents and young people has been reducing in Brazil, owing to factors like the fertility decline and increase of the life hope expectation. In 1997, there were 78,1 million of people from zero to 24 years old, almost half of the Brazilians, and in 2007 this number increased to 82,4 million, representing $43,4 \%$ of the total population in the country.
Nevertheless, despite the social indicators point out some improvements in the direction of this specific population, such as, the reduction of the child mortality and the enlargement of the battle against child labor, there are still aspects that demand an urgent attention, for example, the improvement of teaching quality and violence fighting. Moreover, the analysis indicates that poverty $^{3}$, although it has been decreasing in the last ten years, reaches in the most intense way, children and young people.

Poverty, according to IBGE, also harms the population access to school, above all in the first years of age, because the chance of a four to sixyear old child to go to school increases as per the family income situation. On the other hand, it is almost universalized the education for the individuals from seven to fourteen years old, although this learning quality is still very poor and many Students do not learn how to read and write until they reach the age of ten. We also stand out the fact that many of the fourteen-year old young people (204,8 thousand, in 2007) do not go to school. From 1997 to 2007it was possible to note an increase of the young people percentage between 16 and 17 years old, who only dedicated themselves to studying (from $45,5 \%$ to $54,8 \%$ ), reducing the number of those who only go to work (from $16,5 \%$ to $10,2 \%$ ) or the ones who did housework only (from $11,1 \%$ to $8,3 \%$ ).

With the discussion of the adolescence concept and presenting some characteristics of this age in the Brazilian scenario, we will analyze the meaning of the term under psychosocial risk situation and present studies about the psychosocial vulnerabilities for this human development stage.

\section{Psychosocial vulnerabilities in the adolescence period}

The way we find the theme of psychosocial risk in specific studies, that is, in researches on risk factors or adversities that may harm people's development throughout their vital cycle, we can observe that such condition can occur at any moment and not exclusively during childhood or adolescence. Moreover, we can also consider, besides the individual, families or communities that are under risk situations.

In relation to the adolescents, particularly, some authors ${ }^{16}$ indicate the different levels of risk they can be submitted: physical, psychological, economic, sociocultural etc. On the other hand, the protection factors that the young people acquire in adverse contexts of development (in risk situation) must also be approached for a broader compression of the subject in question.

These studies reveal as risk factors: the drug use, the difficulty to control aggressiveness, the history of physical and psychological maltreatments, low education levels, troubled family relationship and the existence of family member with low education level, disqualified to work and involved

3 The IBGE document ${ }^{15}$ explains that poor people were considered the ones living with a monthly income of until $1 / 2$ minimum wage per capita, what represented $30 \%$ of the Brazilians, in 2007 , and $46 \%$ for the ones between zero and 17 years old, for the same year. 
with criminality. Regarding the protection factors, we stress out the social support networks (school, job, friends and institutions), the skills to defend and negotiate rights and interests, positive images of others, high self-esteem and family supervision.

However, we can also find, in this literature, the need for other researches that investigate both factors, because it is possible that each risk factor has specific protection factors. Besides, the interpretation given by the individuals submitted to a certain stress will be determinant for the degree of damage in their development. This is one of the reasons why the Authors discuss the risk factors associated to protection factors, because not all the individuals submitted to the same psychological and/or social stressors will become vulnerable to other harmful aspects to their development, as the involvement with criminality, for instance.

In this sense, we briefly mention some studies $^{16,17}$ that deal with the resilience concept, owing that an adverse condition considered as risk, is always related to it. Regardless of indicating that this concept is in progress, they define the resilience, in a general way, as being someone's capacity to give a positive response, despite all the misfortunes lived throughout all the human development, the demands imposed to life. Therefore, this concept covers the possibility of thinking about the discontinuity of the problems experienced by a younger population as the ones born in violence and chemical dependency contexts etc., not being condemned to having problems (social, health etc.) at further stages of their development.

However, this area's studies clarify that being resilient does not mean become immune to the life stress, nor even being invulnerable to the suffering coming from the conditions lived under adversities, violence and catastrophes, but it denotes a capacity to overcome these hard moments sometimes lived. This way we deal with psychological processes that may create the overcoming of crises and adversities which some people experience at certain moments in their lives. Furthermore, it is necessary to consider the resilience concept, as well as the risk and protection factors, from the values and meanings belonging to a certain culture, taking into consideration its social and historic construction.

This way, the resilience concept, understood as a human ability to overcome adversities, is incorporated by a theoretical perspective named Positive Psychology that aims at understanding the issues that promote the healthy psychological development. Therefore, resilience depends on the individual's constitutional foundations and on the environmental ones, as well. This way, resilience refers not only to personality traits, but also to social contexts and to each person relationship networks.

Moreover, the permanent interaction that also occurs between the risk and protection factors, since the risks (life negative events) predisposes people to present physical, psychological or social problems and the protection factors may provide an improvement in the individuals' response or certain risks. Therefore, resilience can be defined as the processes that will operate in the presence of risk with the intention to produce healthy reactions on people.

A study about the risks, which some adolescents from the Brazilian Federal District ${ }^{18}$, going to public schools in areas considered as psychosocial risk would be exposed to, discusses precisely the strategies developed by them with the intention to promote health. Thus, we can name as risk indicators the violence (violence acts and confrontation with the intrafamily law and in the community), the exposure and contact with drugs, suicide attempts and the concern with STDs. As protection factors, it was found the use of protection during sexual relations, living with the family and the expectation of help from neighbors and community leaders.

In relation to violence, specifically, it was observed that the infringement processes are part of these young people context, although, they do not get involved with crimes \% they claim to have at least one family member that has already been arrested for that reason. They also reveal the lack of safety regarding living in these communities, owing to the high drug dealing, burglary and robbery index inside the place where they live. Regarding the use of drugs, the biggest risk is the use of alcohol that seems to be important in the adolescents everyday life and not for illicit drugs.

In another research ${ }^{19}$, also related to young people studying at public schools in the Brazilian Federal District (between 13 and 27 years old), the main risk factor found for the development was the low socioeconomic level they are submitted to. Associated to such condition, other factors that contribute for the risk were indicated, like the drug use/dealing and living among violence. Nevertheless, this study indicated protection networks for these adolescents regarding family, schools and friends contexts, besides personal factors that, in this sense, contribute for the selfesteem and religiosity/spirituality.

Regarding poverty situations ${ }^{16}$, in general, we call attention for the fact of not being considered as risk, a priori, for children and adolescents, without an adequate contextualization. Thus, it is necessary to investigate the perception the subjects have of their life quality, the hope they have in relation to overcoming unfavorable conditions and, besides, the characteristics of the context they live in, the relations that are established in this place, their personal characteristics and the development moment. We stand out family, school and institutions as the environment of human development that can promote resilience, depending on the possible type of inter-relation in these contexts, which must be measured by quality, affection and reciprocity.

We also highlight how the work market and the social protection system can determine $\%$ a greater or lesser degree - a condition of social vulnerability, generically considered, what is equivalent to the high levels of poverty and social inequality lots of Brazilian are exposed to. We must analyze, before the different family arrangements present in the current society, whether any of them would cause a greater social risk for their members. 
Among the other results indicated, we highlight that within the families living an unsafe socioeconomic situation, the presence of children (considered in the study as 16-year old people) denotes an impact three times bigger than the presence of adolescents (from 17 to 24 years old) or even the elderly with pension cover in the event of this family to be vulnerable ${ }^{20}$.

Besides, it seems to be almost indifferent for the vulnerability of this type of family, the fact that the boss (defined by the one owing the higher salary and not for authority criteria) is male or female. In this sense, despite the changes that occur in these families with the insertion of the woman in the work market, there was no change regarding the responsibility she takes for herself in relation to children and dependent old people, causing them to be overwhelmed. In addition, going against the common sense, there is no relevance for the vulnerability if these families are two-parental (the presence of a couple in charge of the family, which the boss is generally the man) or single-parental (the presence of only one person in charge of the family, generally with the woman as the head).

We also point out that the presence of at least one spouse having a job, reduces in a significant way the probability of a family to be vulnerable, regardless the head of the family gender or if the family is single or two-parental. Anyway, the low socioeconomic level constitutes a way of chronical adversity ${ }^{21}$ that can be transformed into risk for some families (poor families, families belonging to popular classes and families with low income, denominated in the works evaluated by the Authors), although this does not occur with all families, because it also depends on the protection factors that can moderate the poverty effects.

In relation to violence, we stand out the importance given by the international bodies to this discussion, showing their concern with the world population at the ages of 10 and 29 years old, specifically, taking into consideration they are the main aggressors and victims. This way, some situations tend to increase these indices of violence, which are higher in the Latin America and African countries, and smaller in the East of Europe: violent experiences during childhood, being members of gangs and having access to fire guns, living under long war periods, social exclusion and poverty ${ }^{21}$.

About these last aspects, the social exclusion and poverty, some factors would be associated to the murders against adolescents, having the young people as the main aggressor of crime. The adolescents, who are victims of this kind of crime seem to be marked by an existential path that can be defined by the 'no', that is, were not provided with satisfactory infra-structural conditions for their development, and without this essential assistance, decided to follow the delinquency path and kept on committing offenses until being murdered by other young people.

Therefore, we highlight that violence among adolescents cannot be explained by the mere presence of personal conflicts, but it is related to the structural violence, which they are part of, in which the fragile socioeconomic insertion of their relatives and the urban segregation they live are included. This way, we need to emphasize the importance of the relation that must exist between the conditions of life of the young populations (poverty, social exclusion, drug dealing and structural violence) and the mortality indices ${ }^{21}$.

There are other analyse ${ }^{19}$ that stablish a greater risk among the young people fin order to allow crimes to happen or for their indirect participation, pointing out some aspects that represent different faces of violence: witnessing violent actions in the community they belong to; being often exposed to violent images through the media; feeling threatened by violence and impotent in the face of it; and believing that violence is a real solution for social conflicts.

Moreover, unfavorable socioeconomic factors - as poor quality of houses and low schooling, among others - are also associated to a bigger risk so that the Young people get involved with criminality, because the perception of the consume impossibility of material goods can make them more motivated. To this context, it is added the discussion referent to the expansion of drug dealing, which violence, usually, is how the conflicts are solved.

These studies ${ }^{19}$ even reveal that it is not harmful the fact that just by being a victim of violence, but being a witness as well, because these circumstance could make someone to have psychological problems (anxiety, depression) or social ones (social isolation behavior). The same way, we stand out a research ${ }^{22}$, about the antisocial behavior ${ }^{4}$ among 11 to 17-year old adolescents from a low income suburb in the city of São Paulo, which are the risk factors for the emergence or continuity of the behavior in the young people, the fact they belong to a family environment and a violent community.

Regarding the family importance, mainly, in the development of offending conducts carried out by the Young ones with a low socioeconomic level ${ }^{23}$, we point out five relevant risk factors: 1 ) antisocial behavior of relatives \% with the use of drugs, more related to the father, brother and uncles; and the assaults, more related to brothers, cousins and uncles; 2) number of siblings \% the bigger the family is, the higher the chances of risks of coercive and negligent practices to occur and lower the affection, attention and per capita income indices; 3 ) drug use by adolescents; 4) conflicts in the family; 5) parental educative practices, such as, follow-up, privation of material privilege, physical punishment, delegating responsibilities for others, negligence and reinforcement of inadequate behavior. Besides these factors, we point out that the family institution itself, as a support network for adolescents, can represent an important factor for the involvement of adolescents with offenses and drug dealing, since there is a lack of people that might play the role of risk protectors.

4 The antisocial behavior are defined by Authors of the research mentioned ${ }^{22}$ as externalization problems of the development, characterized by aggression acts and violation of rules. 
Therefore, the adolescents exposure to different kinds of violence in their everyday life contributes in an important way so they learn a violent behavior model. Before this exposure to violence, the adolescents can either react by isolating themselves or manifesting depressive thoughts by the unsafe feeling created in relation to family and community they are part of, or they can become a little sensitive regarding violent acts and start to reproduce the model learned, creating a cycle of violence ${ }^{22}$.

In this context, we also mention the intrafamily violence and the violence in the community as ways of victimization that intensively affect the life of adolescents, besides the police violence, which make the young ones as the main victims. Regarding the violence present in the community, we highlight that young people witness two times more violent actions occurring near their houses than the adults, including the scenes of physical aggression, drug dealing, people injured by firearms and people being murdered. Besides all this exposure to violence, which are lived by the young ones, there is also the probability of them to be victims of the direct violence, with verbal or physical aggressions, offer to do drugs, relatives threatened to die and police aggressions ${ }^{22}$.

We can add to this panorama the broad violence expression - structural, family and social - several risk situation the young ones can manifest their violent behavior, for instance, possession of firearms, frequent participation in fights, cultivation of the violent masculinity and alcohol influence and other drugs. These risk factors can be organized in four different levels that could act in a simultaneous way and increase the vulnerability of the young people for delinquency: 1) individual (biological characteristics, as subtle neurologic damage, or psychological ones, like, impulsivity); 2) relational (family mistreatment, delinquent friends influence); 3) community (high indices of criminality, with the presence of gangs, fire guns and drugs); 4) social (income inequality, cultural norms that identify violence as a way to solve conflicts). According to this study, ${ }^{22}$ the offenses considered more frequent among the adolescents that end up committing transgressions, are robbery, homicide, burglary and drug dealing.

There are other Authors ${ }^{24}$, who, on the other hand, study school adolescents from different economic strata and discuss the factors associated to the conducts of violent coping among them. Among other aspects, we highlight the few studies about the fact of young people's lives without any legal problems referent to its conduct that predispose them to a violent behavior. The fact that violence is present at people's lives early, including the family, school and society is causing serious individual and social damages, because some individuals incorporate the violence in their life style, depending on the life conditions being more favorable or not. In this sense, researches about youth under risky situations in Brazil ${ }^{25}$ indicate the school as an important protection factor to the juvenile delinquency, as well as the psycho-affective and socioeconomic connections coming from the family.

We also inform, as a conclusion, that the Brazilian Young people (between 15 and 24 years old), when compared with the adult population, are in a favorable situation regarding the education and the use of tobacco, and both stages are in the same position related to work force. However, the youth is exposed to risk factors of such severity (risky sexual activities, unemployment and victimization due to violence), which demand a special attention at this moment of life. Thus, it is necessary to understand the differences that mark people at this age, considering the geographic region where they live, as well as gender and race.

Lastly, as established by these researches ${ }^{25}$, it is necessary to understand the violence that fully affects the development of 35 million adolescents between 10 and 19 years old, considering the situations, which they are victims or aggressor, because this is the population that kills and dies the most in Brazil and in Latin America. This way, it is important to remember the history of poverty, the inequality and the lack of rights guarantee that perpetuates the exclusion and segregation picture of the Brazilian population, with even more severe damages to the young ones. As illustration, we highlight that, in the beginning of the 2000-decade, $45,9 \%$ of the Brazilians aged at 10 and 14 years old, and $37,5 \%$ between entre 15 and 19 years old living under poverty situation, once there is an overrepresentation of poverty between black children and adolescents.

Before this panorama, we call attention for the interventions that can be thought mainly aiming at promoting the value of life of the young population under psychosocial risk situation, in a way to prioritize the prevention so they cannot continue endorsing the violence statistics in Brazil, which will be considered the victims or the aggressors of this type of crime against life. In our case, we have been reflecting for a while on the possibility of such interventions through education in moral values, although, we are aware of the research relevance that prioritize the comprehension of violence before these actions can be actually better defined, as well as the objectives that with them would be possible to be expected. We hope this present work is able to contribute for this purpose. 


\section{REFERENCES}

1. Ministério da Saúde. Secretaria de Vigilância em Saúde. Impacto da violência na saúde dos brasileiros. In: Minayo MCS. Violência: um problema para a saúde dos brasileiros. Brasília: 2005; p.9-42.

2. Guareschi NMF, Weber A, Comunello LN, Nardini M. Discussões sobre violência: trabalhando a produção de sentidos. Psicol Reflex Crít. 2006; 19(1):122-30. DOI: http://dx.doi.org/10.1590/ S0102-79722006000100017

3. Silveira MAS, Maruschi MC, Bazon MR. Risk and protection for adolescents engaged in practices of offensive conduct. J Hum Growth Dev. 2012; 22(3): 348-57.

4. Dornelles JRW. O desafio da violência, a questão democrática e os direitos humanos no Brasil. Direito, Estado Sociedade. Rio de Janeiro: 2006; 9(29):213-221. DOI: http://dx.doi.org/ $10.17808 /$ des.29.293

5. Ruotti C, Freitas TV, Almeida JF, Peres MFT. Graves violações de direitos humanos e desigualdade no município de São Paulo. Rev Saude Pública. 2009; 43(3):533-40. DOI: http:// dx.doi.org/10.1590/S0034-89102009 005000027

6. Zaluar A. Agressão física e gênero na cidade do Rio de Janeiro. Rev Bras Ciênc Soc. 2009; 24(71):9-24. DOI: http://dx.doi.org/10.1590/ S0102-69092009000300002

7. Prando CCM. Sobre a paz e o Estatuto do desarmamento. Novos Estudos Jurídicos. 2007;12 (1):137-144. DOI: http://dx.doi.org/ 10.14210/nej.v12n1.p137-144

8. Conselho Federal de Psicologia. Avaliação psicológica: Diretrizes na regulamentação da profissão. In: Nascimento RSGF, Werlang BSG. Avaliação psicológica para concessão de registro e/ou porte de arma de fogo. Brasília: 2010.

9. Gontijo DT, Alves HC, Paiva MHP, Guerra RMR, Kappel VB. Violência e saúde: uma análise da produção científica publicada em periódicos nacionais entre 2003 e 2007. Physis. 2010; 20(3):1017-54. DOI: http://dx.doi.org/ 10.1590/S0103-73312010000300017

10. Macedo EOS, Conceição MIG. Group actions to promote the adolescents health. J Hum Growth Dev. 2013; 23(2):222-30.

11. Papalia DE, Olds SW, Feldman RD. Desenvolvimento humano. Porto Alegre: AMGH; 2006.

12. Schoen-Ferreira TH, Aznar-Farias M, Silvares EFM. Adolescência através dos séculos. Psicol Teoria Pesq. 2010; 26(2):227-34.

13. Fonseca DC, Ozella S. As concepções de adolescência construídas por profissionais da Estratégia de Saúde da Família (ESF). Interface. Botucatu: 2010; 14(33):411-24. DOI: http:// dx.doi.org/10.1590/S1414-32832010000 200014

14. Vieira JM. Transição para a vida adulta no Brasil: análise comparada entre 1970 e 2000. Rev Bras Estudos Popul. 2008; 25(1):27-48. DOI: http://dx.doi.org/10.1590/S0102-30982008 000100003
15. Brasil. Instituto Brasileiro de Geografia e Estatística (IBGE). Síntese de Indicadores Sociais: uma análise das condições de vida da população brasileira 2010. Estudos Pesquisas. Rio de Janeiro: 2010; (23). [ cited 2015 july 18] Available from: http://www.ibge.gov.br/home/ estatistica/populacao/condicaodevida/ indicadoresminimos/sinteseindicsociais2010/ SIS_2010.pdf

16. Poletto M, Koller SH. Contextos ecológicos: promotores de resiliência, fatores de risco e de proteção. Estudos Psicol. Campinas: 2008; 25(3):405-16. DOI: http://dx.doi.org/ 10.1590/S0103-166X2008000300009

17. Oliveira MA, Reis VL, Zanelato LS, Neme CMB. Resiliência: análise das publicações no período de 2000 a 2006. Psicol Ciênc Profissão. 2008; 28(4):754-67.

18. Brasil KT, Alves PB, Amparo DM, Frajorge KC. Fatores de risco na adolescência: discutindo dados do DF. Paidéia. Ribeirão Preto: 2006; 16(35):377-84. DOI: http://dx.doi.org/ 10.1590/S0103-863X2006000300008

19. Amparo DM, Galvão ACT, Alves PB, Brasil KT, Koller SH. Adolescentes e jovens em situação de risco psicossocial: redes de apoio social e fatores pessoais de proteção. Estudos Psicol. Natal: 2008; 13(2):165-74. DOI: http:// dx.doi.org/10.1590/S1413-294X2008 000200009

20. Lavinas L, Nicoll M. Atividade e vulnerabilidade: quais os arranjos familiares em risco? Dados. 2006; 49(1):67-97. DOI: http:// dx.doi.org/10.1590/S0011-5258200 6000100004

21. Prati LE, Couto MCPP, Koller SH. Famílias em vulnerabilidade social: rastreamento de termos utilizados por terapeutas de família. Psicol Teor Pesq. 2009; 25(3):403-8. DOI: http:// dx.doi.org/10.1590/S0102-37722009000 300014

22. Sá DGF, Curto BM, Bordin IAS, Paula CS. Exposição à violência como risco para o surgimento ou a continuidade de comportamento antissocial em adolescentes da região metropolitana de São Paulo. Psicol Teor Prática. 2009; 11(1):179-188.

23. Pacheco JTB, Hutz CS. Variáveis familiares preditoras do comportamento anti-social em adolescentes autores de atos infracionais. Psicol Teor Pesq. 2009; 25(2):213-9. DOI: http:// dx.doi.org/10.1590/S0102-37722009000 200009

24. Câmara SG, Sarriera JC, Carlotto MS. Fatores associados a condutas de enfrentamento violento entre adolescentes escolares. Estudos Psicol. Natal: 2007; 12(3):213-9.

25. Unidade de Gerenciamento do Brasil. Jovens em situação de risco no Brasil, Vol. II: Relatório Técnico. Brasília: 2007; [ cited 2015 july 18] Available from: http://www-wds. worldbank.org/external/default/ WDSContentServer/WDSP/IB/2007/07/30/ 000020953 20070730105804/Rendered/PDF/ 323100v20PORTU1IIORelatorio0Tecnico.pdf 


\section{Resumo}

Introdução: Verificamos um destaque para a mortalidade por causas externas, principalmente os homicídios que ocorrem entre a população jovem masculina, caracterizada como agressora e vítima, representando atualmente um dos maiores problemas para a saúde pública. O Brasil tem, então, se preocupado com intervenções direcionadas à diminuição de vítimas jovens da violência e à promoção de uma cultura da paz. Objetivo: Para esta finalidade, julgamos fundamental conhecer os riscos psicossociais que podem estar presentes na trajetória de desenvolvimento dessa população. Este é o propósito maior deste estudo. Método: Para compreender as violências no cenário brasileiro contemporâneo, apresentamos alguns resultados alcançados por meio da pesquisa bibliográfica. Resultados: Assim, pesquisas recentes apontam que os fatores de risco que podem acometer jovens ao longo de seu ciclo vital são de vários níveis: físico, psicológico, econômico, sociocultural etc. Por outro lado, os fatores de proteção que os jovens adquirem em contextos adversos também terão que ser abordados para uma compreensão mais abrangente do tema em questão. Assim, encontramos como relevantes fatores de risco: baixo nível socioeconômico e percepção da impossibilidade de consumo de bens materiais; condições precárias de moradia; vivência e exposição à violência intrafamiliar e na comunidade, incluindo a violência policial; exposição e contato com drogas; histórico de maustratos físicos e psicológicos; baixa escolaridade; existência de familiares com baixa escolaridade, desqualificados para o trabalho e envolvidos com a criminalidade; acesso a armas; pertencimento a gangues; experiência de longos períodos de exclusão social e de pobreza; sentimento de ameaça pela violência e impotência diante da mesma; e crença de que a violência é uma solução legítima para conflitos sociais. Quanto aos fatores de proteção, os estudos salientaram redes de apoio social (escola, trabalho, amigos, instituições), habilidades para defender e negociar direitos e interesses, imagens positivas dos outros, expectativa de ajuda por parte dos vizinhos e da comunidade em geral, autoestima elevada e supervisão familiar. Foram destacados também os fatores pessoais que contribuem nesse sentido, como a autoestima e a espiritualidade. Conclusão: Contudo, a interpretação dada pelo sujeito submetido a determinado estresse será determinante para o grau de prejuízo em seu desenvolvimento. Este é um dos motivos pelos quais os fatores de risco devem ser associados aos fatores de proteção, pois nem todos os sujeitos submetidos aos mesmos estressores psicológicos e sociais se tornarão vulneráveis a outros aspectos nocivos ao seu desenvolvimento, como o envolvimento com a criminalidade, por exemplo. Por esta razão, descrever grupos e fatores de risco se torna fundamental para buscarmos intervenções específicas, pois sexo, faixa etária, cor, espaço geográfico e condições sociais e econômicas são variáveis importantes para especificar formas de incidência e prevalência da violência. Contudo, será no indivíduo, considerado como um todo (físico e psíquico), que a violência se efetivará, seja como vítima ou agressor.

Palavras-chave: violências, adolescentes, risco psicossocial. 